\title{
PSYCHODIAGNOSTIKA \\ JAKO PSYCHOLOGICKÁ APLIKACE
}

MARKÉTA NIEDERLOVÁ, JIŘí ŠÍPEK

\begin{abstract}
Abstrakt: Autoři poukazují, že psychodiagnostika nesmí být chápána jako množina konkrétních metod a testů, které jsou popsané v učebnicích a manuálech, a které je možné víceméně jednoduše použít na diagnostikování nějaké psychické vlastnosti, stavu apod. To, co je v psychodiagnostice podstatné a přehližené, je potřeba formulování problému, rozvažování kontextu, potřeby hloubky diagnostického záběru apod. Dále autoři procházejí některé vybrané oblasti psychodiagnostiky, jako jsou např́iklad postupy klinické, postupy využívající projektivní metody atd. Přitom autoři stále upozorňují na potřebu zdůvodňování, co se diagnostikuje, proč a jak nejvhodněji.

Klíčová slova: psychologie, psychodiagnostika, metoda, test, psychodiagnostická rozvaha

\section{Psychodiagnostics as a psychological application}

Abstract: The authors point out that psychodiagnostics must not be understood as a set of specific methods and tests, which are described in textbooks and manuals, and which can be more or less simply used to diagnose some psychichological personality quqlities, states, etc. What is essential and overlooked in psychodiagnostics is the need to formulate the problem, consider the context, the need for depth of diagnostic scope, etc. Furthermore, the authors go through some selected areas of psychodiagnostics, such as clinical procedures, procedures using projective methods, etc. The authors still point out the need to justify what is diagnosed, why and how best.
\end{abstract}

Keywords: psychology, psychodiagnostics, method, test, psychodiagnostic reasoning https://doi.org/10.14712/23366486.2020.8

\section{Úvod}

Následující text si neklade za cíl předložit vědeckou studii ve smyslu formulování hypotéz, jejich ověrování apod. To je v psychologii bezpochyby důležité a tím se také psychologie stává oborem, který si nárokuje co největší exaktnost a vědeckou vážnost. Vedle toho je však psychologie odedávna disciplínou apelující na disciplínu myšlení, schopnost chápání více druhů vztahů, využívání imaginace, empatického nabízení intervence v situaci různých lidských a mezilidských problémů a trápení. My se v této chvíli zamýšlíme nad složitostí vazeb a provázanosti proměnných v oblasti psychodiagnostiky, tedy poznávání a doslova umění poznávání v oblasti psychiky. Naše (a jistě nejen naše) zkušenost nás vede $\mathrm{k}$ tomu, že zdaleka nestačí znát co nejvíce psychodiagnostických metod, tedy testů, dotazníků apod., ale že je k tomu nutné dodávat vlastní kritické přemýšlení, odstup a nutně i kreativitu. Tedy všechno to, co lze jen obtižně podat $\mathrm{v}$ učebnicích, ale $\mathrm{k}$ čemu se 
dochází zkušeností. Zvláště citlivá je z tohoto hlediska oblast projektivních metod. Proto jí také věnujeme zvláštní pozornost.

V tomto směru chceme kolegům a studentům, kteří se psychodiagnostice věnují, alespoň trochu pomoci, inspirovat je, povzbudit, aby se nebáli vlastního př́nosu. Ovšem vždy dobře zváženého!

\section{Psychodiagnostika je oblast praktického využití psychologie}

Studium psychodiagnostiky je jednou z nejpodstatnějších oblastí psychologie, ne-li tou nejdůležitější. Na rozdíl od psychoterapie, kde vedle psychologů pracují také lékaři a sociální pracovníci, má psychodiagnostika své těžiště v psychologii a psycholog je v této oblasti stěží nahraditelný. Dobrým důvodem je příprava a vzdělávání širšího spektra, které podpoří psychologovo porozumění diagnostikovanému problému, volbě diagnostického postupu i vlastnostem (výhodám i omezením) diagnostického nástroje. ${ }^{1}$ Však jsou mnohé psychodiagnostické testy dostupné jen vystudovaným psychologům a u některých komplexnějších a náročnějších testů je dnes vyžadován i poměrně intenzivní postgraduální výcvik (např. u Wechslerova inteligenčního testu, MMPI, Rorschachova testu atp.).

Žádný sebedokonalejší test však nemůže suplovat pečlivé a vycvičené psychologovo kritické myšlení, které je tou nejlepší zárukou smysluplných diagnostických závěrů. $\mathrm{Z}$ toho také plyne, že dovednost takového myšlení je základním diagnostickým nástrojem. Bez něho ztrácí jakýkoliv moderní test na své hodnotě. Takové pečlivé myšlení a zvažování všech souvislostí může být nezřídka dobrým vstupem do př́ípadné další psychologické intervence (ř ̌šení daného problému, poradenství, psychoterapie). Praxe nabízí takových situací poměrně dost. Představme si naprríklad, že za psychologem přichází klient s (pracovní, anebo stanovenou) psychiatrickou diagnózou deprese, resp. anxiózně depresivního syndromu. Psycholog se sice může omezit na poměrně jednoduché ověření diagnózy za pomoci vybraných testů (od těch nejjednodušších, jakou je např. Beckova nebo Zungova škála deprese, až po komplexní, jakým je test Rorschachův) a pravděpodobně tak potvrdit prrítomnost deprese v psychologickém obraze, anebo může své vyšetření pojmout komplexněji. Při vyšetření se může například postupně vyjevovat osobnostní základ poruchy, jako je chronický nedostatek jistoty, její stálé hledání podložené pravděpodobně již ranou poruchou vývoje attachementu atp. Výsledkem bude psychologův poukaz, že více či méně zjevná symptomatika spočívá na mnohem hlubších kořenech a tomu je také třeba přizpůsobit terapii. To je jistě pouze jeden př́klad za mnohé další.

Nesmíme však zapomínat na podstatu otázky, proč takovou psychodiagnostickou práci provádíme. Ukazování na složitější terén se sice jeví jako zodpovědné a diagnosticky „poctivější“, ale nemusí tomu tak vždy nutně být. Stačí si opět představit situaci, kdy je psycholog požádán o diagnostiku psychologické situace ve smyslu, zda jde skutečně o rozvoj deprese, anebo o somatizaci na jiném podkladě atp. Zdánlivě jednoduchá diagnostická situace může být velmi důležitá pro psychiatrovo rychlé nasazení vhodného farmaka, které dotyčné osobě také rychle a efektivně uleví.

\footnotetext{
Informace o použivaných psychodiagnostických metodách u nás nalezne zájemce v běžně dostupných publikacích. Především to jsou učebnice Svobody, M., Humpolíčka, P. a Šnorka, V. (2013) a Stančáka, A. (1996). Konkrétním metodám se věnuje editorsky například Čermák, I. a Fikarová, T. (2012) v př́ípadě tematicko-apercepčního testu a Lečbych, M. (2016) se zaměřením na Rorschachův test atd.
} 


\section{Otázka po cíli a smyslu diagnostické práce}

Taková otázka je vždy zásadní. Z ní také musí jasně vyplynout, které konkrétní postupy budou relevantní. Snad hned na začátku našeho textu bude užitečné připomenout podstatný moment. Totiž, že každé psychodiagnostické vyšetření musí být jasně určené, tedy musí být zřejmé, k jakému účelu bylo vyhotovené, jaký problém má vyšetření pomoci řešit a pro koho je určené. V našem textu se dílčích otázek této oblasti ještě dotkneme.

Psychologové, kteří se svojí diagnostickou praxí začínají, mívají tendenci sestavit bohatou baterii s předpokladem, že více metod také více zachytí. Každá metoda bezpochyby něco zachytí, ale opět je zde otázka „co s tím?“ Mozaika metod vytvoří stejně složitou mozaiku výsledků, které mohou každý směřovat jinam a již vůbec ne žádoucím směrem. A který směr diagnostikování je v takovém případě vlastně žádoucí? Podobným nešvarem je rozhodnutí ještě přidat nějaký test vlastně jen proto, že zbývá čas a mohli bychom dostat další zajímavé informace. Nezrrídka to bývá něco z oblasti kresebných testů, protože ty se jeví být nezátěžové a širokospektré. Takový postup je však dokonce $\mathrm{v}$ rozporu s dalším principem etické psychologické práce. Klienta bychom neměli zatěžovat žádným nadbytečným diagnostickým postupem, než jaký je jasně zdůvodnitelný a směřující k zodpovězení stanovené otázky, resp. pomáhající takovou odpověd' podpořit (mající tedy inkrementální validitu). Je třeba se zbavit jedné ulpívající fikce; že totiž psychodiagnostika představuje více či méně jasné postupy, jak provádět diagnostickou práci. Jinými slovy jde o mylnou představu blížící se mechanické psychotechnice s inventářem testů, dotazníků, postupů a jim odpovídajících zadání, oblastí, norem atp.

\section{Psychodiagnostická rozvaha}

Zde je na místě zmínit důležitost toho, čemu říkáme „psychodiagnostická rozvaha“. $\mathrm{Na}$ začátku této rozvahy bývá většinou více či méně přesná zakázka vyšetření. Velmi často s ohledem na komplexnost problému je psycholog nucen pracovat už s touto počáteční informací. Znamená to klást si celou řadu otázek, a tím cíl diagnostiky (někdy společně se zadavatelem či žadatelem) zpřesňovat. V prvé řadě si je třeba ujasnit, kdo má být psychologicky vyšetřen (zda jde o dítě, či dospělého, o jedince, anebo o skupinu) a dále také, do jaké oblasti vyšetření směřuje (naprríklad do oblasti poradenské, pracovní, sociální, klinické, forenzní aj.). K formulaci zakázky výrazně přispívá výběr a pojmenování zjišstovaných psychických fenoménů či celků (schopnosti, vlastnosti, dovednosti, stavy, procesy, vývoj atp.). Tímto postupem si dílčí cíle našeho „poznávání“ zpřesňujeme. Dostáváme se tak k odpovědím na otázky: Koho chceme poznávat a proč? Co chceme zjišt'ovat? Jak si charakterizujeme předmět poznávání? Komu je vyšetření (posudek atp.) určené? Nelze opominout ani okolnosti, které souvisí s plánováním diagnostického procesu, tedy co z našeho pohledu bude jeho realizace obnášet, nevyjímaje nároky ze strany zadavatele či žadatele: Jaké jsou nároky na čas, prostor, př́íp. finanční zajištění? Jaké jsou dosud známé proměnné na straně psychologa (např. znalosti, dovednosti, zkušenosti)? Jaké jsou dosud známé proměnné na také straně klienta (např. omezení daná onemocněním, jazykové možnosti, smyslová omezení)? A jaká jsou specifika daného zkoumaného jevu?

Až na základě zodpovězení uvedených otázek můžeme začít uvažovat o volbě konkrétních postupů či metod. Přičemž psycholog-diagnostik je povinen zvažované nástroje 
dobře ovládat, tzn. znát jejich teoretická východiska, psychometrické charakteristiky, způsob jejich administrace, vyhodnocení a z toho vycházející interpretace. Velmi často má volba postupů či metod povahu diskusní, kdy hledáme na základě dostupných informací ty nejvhodnější. Přitom zvažujeme na nejobecnější rovině i cesty „extraspekce“ či „,introspekce“ nebo z jiného pohledu cesty „klinických“ či „testových“ postupů. V některých př́ípadech může být tato část práce standardnější, tedy již předem daná dosud užívanými a prověřenými postupy či bateriemi testů speciálně vytvořenými pro konkrétní diagnostické zakázky či specializovaná pracoviště. Zvažujeme i uplatnění a způsob administrace vybraných metod (osobní setkání, zacvičený administrátor, možnosti internetu atp.) a s tím související způsob záznamu informací. Vyhodnocení výstupů zvolených metod má většinou povahu kvantitativního či kvalitativního rozboru, který je závislý na pravidlech interpretace konkrétních postupů či metod. V některých př́padech nemusí nutně jít jen o zpracování dat povahy číselné, resp. digitální. Vždy je zde také větší či menší prostor pro intuici, která je z velké části dána zkušeností na straně psychologa-diagnostika. V každém př́padě výstup takového diagnostického procesu musí být vztažen k původní zakázce vyšetření. Může obsahovat i další diagnostický záměr, pokud je požadován nebo je pro zpřesnění závěrů žádoucí. V některých př́ípadech jsou součástí výstupu i doporučení pro následnou psychologickou či psychoterapeutickou praxi.

\section{Psychologická diagnostika}

Stanovení diagnózy je otázkou lékaře, který je zodpovědný za zhodnocení somatického i psychického stavu. Vodítkem mu jsou mezinárodně uznávané manuály nemocí (ICD-10, ICD-11, DSM V). Psycholog sestavuje a pořizuje diagnostiku psychologickou, vycházející ze znalosti jak psychopatologie, tak i psychologie vývojové, sociální, psychologie osobnosti a samozřejmě znalosti psychologické metodologie. Výsledkem je podložená představa o funkčním stavu psychiky dané osoby, jejích slabých i silných stránkách, vyhlídkách, př́ípadně možnostech psychologické intervence atp. Znalost zmíněné psychologické metodologie psychologa vybavuje pro situace zvažování, jakým způsobem sestavit postup vlastního testování, které metody použít a jak je vyhodnocovat. Ale vede ho také především $\mathrm{k}$ formulaci otázky, která je zodpověditelná. $\mathrm{V}$ tom se tedy psychodiagnostik-psycholog podobá výzkumníkovi, který nepostupuje rigidně podle předem daného diagnostického algoritmu nebo manuálu, ale sestavuje si vlastní „hypotézy“.

Využijme př́kladu. Psycholog napsal ve svém závěru (mimo jiné) formulaci: simplexní osobnost. Jiný psycholog tento závěr napadl, že diagnóza je výhradně věcí psychiatra. To je jistě zcela správné. Lékař je zodpovědný za stanovení zdravotnické diagnózy podle uznávané klasifikace nemocí. S takovou diagnózou je propojena představa o etiologii dané nemoci/poruchy a také přiměřené terapie. Od ostatních odborníků - a mezi ně patří i psychologové - se očekává, že budou významně pomáhat (napřs. při stanovování diferenciální diagnózy). Psycholog je však ve své odborné prípravě také veden $\mathrm{k}$ tomu, aby stanovoval psychologické závěry, resp. aby prováděl psychologickou diagnostiku. Ta je v řadě směrů širší než diagnostika psychiatrická. Zahrnuje kombinaci anamnestických vývojových údajů se situací sociální, zvážením osobnostních charakteristik, stavem premorbidním, reakcí na chorobu a s výhledem do budoucna. Terminologicky vzato bývá psychologická diagnostika specifická s odvoláním na různé teorie, typologie atp. Psycholog však také 
používá své znalosti psychopatologie. A právě zde se může jeho závěr blížit závěrům psychiatra.

Výše uvedený př́klad „simplexní osobnosti“ může být pěknou ukázkou nedorozumění. Tzv. simplexní osobnost není běžnou psychiatrickou diagnózou a nenalezneme ji v žádném diagnostickém manuálu. Je to jakési pomocné, pracovní označení osobnostní struktury odkazující ke sníženému intelektu, zúžené sféře zájmu, zjednodušení reakcí atp. Důvodem může být předchozí psychické onemocnění, ale i vrozený stav. Psycholog (ale ani psychiatr) by takové označení neměl užívat v závěrech odborné zprávy (např. forenzního posudku), protože jde o nepřesné a málo určité termíny, ale jako pomocné, pracovní označení je těžko napadnutelné.

V souvislosti s daným př́ikladem se objevil názor, že psycholog může stanovovat diagnózu poruchy osobnosti. Vedl k tomu patrně předpoklad, že osobnost je psychologický fenomén, a tudíž i její poruchy jsou psychologickou záležitostí. Nikoliv; pro psychiatra je osobnost jakýmsi souřadnicovým systémem ovlivňujícím chování a jednání vůči sobě a vůči okolnímu světu a hodnotitelným na škále norma-patologie. Výsledek je opět systematizován/kategorizován v rámci zdravotnické klasifikace. Pro psychologa je osobnost a její eventuální poruchy, odchylky zdrojem pochopení její struktury a dynamiky, vysvětlování a predikce chování. Kromě toho může psycholog pomáhat osobnost rozvíjet, stabilizovat atp. Takové představy se přidržují i mnozí studenti psychologie. Klasickou situací je řešení problému ,Jak byste si počinal/a jako psycholog při zadání: zhodnot’te intelekt daného klienta “. Kupodivu nemalá část studentů začíná takto „Použil/a bych nějaký široce zaměřený test inteligence, napřr. ...“. Nejen že jde o nepřiměřené spoléhání se na kvalitu testových pomůcek ve smyslu jejich psychometrických charakteristik, ale především jde o metodologickou chybu. Vždy je třeba mít jasno, jaké vlastnosti (schopnosti, rysy, stavy) chceme co nejpřesněji měřit, a až následně uvažovat o možných technických postupech. Psychologové postupující takovou nepružnou cestou mají tendenci do svých závěrů přepisovat celé odstavce z manuálů, používají zažité obraty. Výsledné závěry bývají př́liš jednoznačné, tvrdé anebo nesrozumitelně kombinované tím, jak byly vedle sebe seřazeny výsledky několika použitých diagnostických nástrojů a psycholog už „neměl sílu“ na jejich tvůrčí a pružnou kombinaci. Není možné argumentovat, že výsledky byly probrané s dotyčným klientem. Klienti, pacienti mohou být výrazně ovlivnitelní a sugestivně podané výsledky vyšetření mohou jakéhokoli člověka přesvědčit o naší „pravdě“. Ani fakt, že si mnozí za podobná vyšetření platí, neznamená, že by takoví klienti byli obezřetnější a k předkládaným výsledkům kritičtější nebo že by žádali hlubší vysvětlení atp. Naopak to může vést $\mathrm{k}$ bagatelizaci vlastního podezření nebo nejistoty - vždyt' za to zaplatili a věnovali vyšetření spoustu času, a ted' by se mělo ukázat, že je vše jinak? A vše je ještě výraznější, když jsou výsledky ,jakoby“v zájmu klienta.

Zajímavě v těchto souvislostech formuluje psychologovu situaci Weiner (1998), když popisuje diagnostický postup, resp. psychologickou interpretaci datového nálezu za použití Rorschachova testu. Jednou z možností, píše Weiner, je opírat se pevně o empirii, o tradovaná data, nálezy a normy. Další možností je opírat se o názory autorit v oboru (co si myslí, jaký je usus atp.). Nejsolidnějším, ale i nejtěžším způsobem (Weiner jej označuje za přístup „konceptuální“), je za „přiměřeného“ využití výše zmíněného, plus svých vlastních zkušeností vytvořit model psychiky, který by mohl odpovídat daným naměřeným datům. Tento model porovnávat s modelem psychiky, která se blíží stavu definovanému nabízenou diagnózou (pokud jde o situaci psychopatologie či diferenciální diagnostiky) 
anebo definovanou psychologickou situací, ve které se daná osoba nachází (situace traumatu, stresu nejrůznějšího typu atp.). Weiner také nezapomíná na interpretaci způsobem „věštecké tabulky“, kdy očekáváme, že se pravda tak či onak vyjeví.

\section{Psychologická diagnostika osobnosti}

Již jsme se zmínili o zásadnosti stanovovat si při diagnostické práci výchozí otázku, problém. Nezřídka jsou psychologové k takovému bezbřehému diagnostikování tlačeni svými kolegy psychiatry, kteří je často žádají obecně o vypracování diagnostiky osobnosti. Představme si psychiku jako „vesmír“ či ,mlhovinu“ bez přesných hranic. Díváme se na to dění relativně úzkou čočkou a máme vysoudit charakter dějů ve „vesmíru“, dynamiku dění, prognózu vývoje atp. Do výsledného obrazu se bude promítat veliké množství fenoménů z různých hloubek vesmíru, budou se překrývat, vzájemně interagovat, zesilovat, budou se řadit vedle sebe, jako by pocházely ze stejného „hnízda“. Jen velmi zkušený astronom dovede tyto jevy rozlišit a hovořit o jednotlivých vrstvách vesmíru a o tamním dění, ale bude také vědět, o jakých vrstvách a děních nemůže říci téměř nic. Takové podobenství lze bez problémů přenést i do oblasti psychodiagnostiky, kdy je zkoumaná oblast psychiky podobně vrstvená, s jevy jednoduššími a jasnějšími, ale také s jevy a strukturami komplikovanými, vzdálenými, málo zřetelnými. V grafologii sice operujeme s řadou charakteristik, včetně globálního (ale nutně neurčitého) dojmu, ale je to stále nesrovnatelně méně, než kolik kombinací a faktů na různé úrovni šíře a obecnosti si lze představit nebo očekávat v onom ,vesmíru“ psychiky. Jednoznačný ,převod“ (až mechanický) znaků písma na jevy psychiky (či obráceně) je absurdní představa.

Koch (1972) podotýká, že při kresbě stromu není strom ničím jiným než právě nosičem projekce. Psychiku vyšetřované osoby je možné si představit v několika vrstvách (resp. několika aspektech osobnosti daného člověka). Každá taková oblast se může projikovat (zde např. konkrétně do kresby stromu). Výsledkem ovšem je kresba (obecně jakékoliv ztvárnění, formace) reflektující souřadně všechny tyto vlivy, ač mají původ v různé ,hloubce“ osobnosti. Mưžeme si opět pomoci prríměrem z astronomie: známé souhvězdí Orionu vnímáme jako jednu rovinu, plochu se všemi hvězdami. Pohled ,z boku“ by nás přesvědčil, že hloubkový rozdíl je obrovský a že tedy jednotlivé hvězdy jsou zástupci různých oblastí vesmíru. To vše musí mít jak astronom, tak v našem prŕípadě psycholog na mysli. Konečný, a řekněme „správný“ výklad struktury, dynamiky a vývoje osobnosti musí pokud možno rozlišovat působení a projev různých hloubek osobnosti na globálním projevu, výrazu atp.

\section{Autodiagnostika}

Pokud chceme tvrdit, že základním diagnostickým nástrojem je psychologova rozvaha, jeho dovednost formulovat otázku a cíl vyšetření, nutně musíme dodat, že vlastně záleží i na osobnosti psychologa. Takto uvažoval i klinický psycholog Hugo Široký (1993, první vydání 1964). Shrňme si stručně jeho podněty k autodiagnostice jako předpokladu k zodpovědné diagnostice někoho druhého. Široký tedy psychodiagnostika vybízí k uprrímnému odpovídání (sobě) otázek typu: Které klinické situace 
a kteří klienti/pacienti mě zneklidňují, přitahují, kde se s nimi nejraději setkávám? Která témata mám tendenci otevírat častěji a kterým se spíše vyhýbám? Jaké jsou moje nejčastější reakce a pocity? Podobná sebeexplorace je bezpochyby důležitá pro profesionální zvládání všech situací jak při diagnostice, tak při intervencích a psychoterapii. Podstatná je pro to supervize v celé šiři psychologického praktikování.

\section{Klinické psychodiagnostické postupy (pozorování, anamnéza, rozhovor, analýza artefaktů)}

Jsou to netestové postupy vyšetření, resp. posudku (assessmentu) používaného všude v psychologii. Netestová diagnostická psychologova práce je mimořádně zodpovědná a nečekaně náročná. Spočívá v dovednosti vést rozhovor, umění kombinovat více či méně strukturované „povídání si“ s klientem. Takových situací je v psychologické praxi překvapivě hodně. Každá úvodní orientace v klientově problematice je otevřenou situací vyžadující citlivé prozkoumání všech důležitých souvislostí, jejich posouzení, vytvoření podložených hypotéz, které mohou být následně podrobněji zkoumány užitím zaběhnutého diagnostického, např. testového postupu, prŕípadně může následovat psychologická intervence. Potřebě vypěstovat si kvalitní psychodiagnostické dovednosti se psycholog tedy nevyhne ani tehdy, když se rozhodne věnovat se psychoterapii. Naopak. Každé setkání s klientem a jakékoliv intervenování vyžaduje souběžné posuzování aktuálního stavu. Fakt, že se tomuto posouzení velmi často nevěnuje vyhrazená, samostatná část setkání, zvyšuje nárok na psychologovu vnímavost a dovednost. Výběr metod je třeba pečlivě volit vždy s otázkou, jaká data nám metoda poskytne, jakou oblast testovaného konstruktu jimi chceme pokrýt. Nebezpečí je v práci se směsí různých typů dat, různých úrovní měření (a tomu odpovídajících škál měření).

Jako príklad si vezměme kombinace dotazníkových, výkonových a projektivních metod. Setkat se s tím můžeme $\mathrm{v}$ různých používaných bateriích $\mathrm{v}$ mnoha psychologických laboratořích. Často můžeme slyšet chválu na pestrost metod a tedy postihování různých osobnostních hledisek testovaných osob. Občas v těchto souvislostech také zaslechneme odkaz na tzv. triangulaci, tedy právě na kombinaci více diagnostických postupů a metod sběru dat $\mathrm{v}$ zájmu podpory výsledné validity celého šetření. Velkým zlozvykem je zaplnění testového času metodou, kterou psycholog obhajuje např. slovy ,je to zajímavá metoda, která může ledacos ukázat“.

\section{Nestandardizované psychodiagnostické postupy}

Téma samo o sobě je užíání kresebných technik a podobných nestandardizovaných postupů. Zásadní je otázka, zda je opravdu třeba je $\mathrm{v}$ dané diagnostické situaci použít. Neznamená to však, že takové techniky zcela vylučujeme z psychologické práce. V některých situacích, např. uvozujících psychologické intervence to může být ku prospěchu věci. Za samozřejmost považujeme, že i tyto techniky patří do rukou zkušeného psychologa. A to také proto, že při jejich použití je zvláště citlivá fáze interpretace, kde je právě psycholog nezastupitelný. U výkonových a dotazníkových metod, které jsou výrazně objektivnější (tedy méně závislé na osobě examinátora), tomu tak není (např. v souvislosti 
s rozvojem počítačových verzí těchto metod). Je jistě pravda, že zde je výklad výsledků méně podmíněn interpretací examinátora, tedy osoby, která testy zadává. Nicméně nikdy není možné zcela nahradit psychologovo vysvětlení, instruování a výsledné interpretování, byt' existuje relativně dost „tvrdých“ dat v kontextu všech ostatních informací (anamnézy, pozorování apod.) a opět jejich vztažení k cílovému testovanému konstruktu, otázce atp.

Naším cílem je zamýšlet se nad možnostmi a nejvhodnější prací s psychodiagnostickými metodami, testy, postupy a způsobem myšlení, jež zároveň zdůrazňuje přístup dostatečně kritický, disciplinovaný a přitom nedogmatický. V psychologické diagnostice se nevyhneme značně komplexní otázce modelů a modelování. Je to oblast dnes již propracovaná, zasahující do několika oborů a my si zde rozhodně nenárokujeme její obsáhnutí a podrobné prezentování.

\section{Psychodiagnostické postupy třídíme podle záměru}

To je jistě z praktického hlediska užitečné. Na jedné straně je to skupina metod založená na psychometrickém základě (resp. na takovýto základ se odvolávající), a na straně druhé to jsou metody spíše se odvolávající na nemetrické výsledky, např. na fenomén projekce, kreativity atp. Zjevně je v tom také náběh na diskusi o kvantitativním a kvalitativním metodologickém př́stupu.

\section{Induktivní a deduktivní stránka psychologické diagnostiky}

Ta první vychází z předpokladu chápání podstatných osobnostních charakteristik, jako jsou jednotlivé kognitivní procesy, osobnost s jejími podstatnými dimenzemi normy (schopnosti, temperament, motivační struktura) i patologie (nap̌r. deprese, psychotické stavy, osobnostní poruchy atp.). Výsledkem je množina dílčích psychologických proměnných (jako jsou určité typy chování v daných situacích, podněty odpovídajících reakcí, zvládání úkolů, nároků, ale i spontánní projevy atp.). Jednoduše řečeno, z předpokládané existence nějakých nezjevných kvalit dedukujeme jim odpovídající projevy. V psychodiagnostické praxi to konkrétně znamená, že nejdříve si vymezíme struktury, o které nám jde, které nakonec chceme nějak postihnout a charakterizovat. Např́klad se rozhodneme, že pro řešení daného úkolu (dejme tomu, že to je zvážení, který obor studia by mohl být pro danou osobu nejvhodnější) by bylo třeba znát úroveň intelektu, hodnotovou orientaci a zájmy. Jinými slovy tvoříme pracovní hypotézy. V druhém kroku budeme hledat konkrétní linie a projevy oněch obecných konceptů (intelekt atp.) a pro ně sestavené diagnostické nástroje. Takové konkrétní linie (např. jednotlivé vlastnosti pozornosti a následně tomu odpovídající měřící nástroje) však nemusí být podstatné pro tu psychickou strukturu, resp. pro tu podobu kognitivních procesů (tedy pro jejich složku, kterou nazýváme obecně pozorností).

To je první část naší diagnostické práce, kterou nelze přeskočit, vynechat. Přesto se to v praxi někdy děje a jakoby př́mo se vstupuje do fáze induktivní. Konkrétně to může mít podobu zkratkovitého řešení, např. v podobě úvahy ,použijeme metodu D2, př́íp. IST a dostaneme tak důležité informace“. Je to de facto skok do jakési jednoduché podoby induktivní psychodiagnostiky zhruba vyjádřitelné př́ikladem „Když vím o dané osobě 
to, co jsem si přečetl v záznamu předchozích vyšetření, když vidím, jak se právě chová, a slyším, co říká, když mám výsledek několika běžných testů (které zhruba ovládám), tak přesáhnu rovinu výchozích premis a usoudím, jaká ta osoba je... “To je ovšem téměř zneužitá induktivní fáze psychodiagnostické práce. Ta skutečně spočívá v usuzování z dílčích premis na nějaký obecnější závěr, ovšem podstatná je relevance oněch premis. Každou metodu, každý dílčí diagnostický postup bychom měli být schopni zdůvodnit a mělo by nám být alespoň v podstatě jasné, jakou výslednou část zamýšleného konceptu (např. onoho intelektu, pozornosti, motivace apod.) pokryjeme, a jestli je to pro potřebný závěr dostačující. Optimální by bylo realizovat psychodiagnostické postupy v přirozeném prostředí. Tedy za takových podmínek, kdy nedochází k nevhodné, nežádoucí redukci působících proměnných a jejich možných interakcí.

Občas můžeme zaslechnout kolegu psychologa, který vyzkoušel nějakou neběžně používanou diagnostickou pomůcku a následně komentoval „Ono to docela zajímavě ukazuje..." Zvláště to platí o projektivních technikách. Představme si situaci, kdy po nějakou dobu (abychom ji prakticky zvládli a byli schopni si plně všímat chování klientů a jejich výsledků v dané metodě) sbíráme pomocí takové metody údaje. A jde-li navíc o metodu málo strukturovanou co do prezentace a vyhodnocování (když to tedy není prostá dotazníková metoda), nasbíráme postupně velké množství údajů v celém rozpětí od kvantifikovatelných (digitálních) až po drobné nuance v chování, situační souvislosti, tón hlasu atp. K této široké škále jevů přidejme vlastní nastavení, očekávání, připravenost „lovce“, míru důvěry, a výsledek se dostaví. Tato dvojí projekce s výsledným množstvím dat na různých úrovních (globální a molární) se postará o tušení vazeb, struktur skrytých a námi nyní odhalovaných.

V zásadě však nelze říci, že je to zcela zavádějící postup. Zkušený psycholog dokáže „nalézt" relevantní (tedy k určenému cíli vyšetření se vztahující) údaje v podstatě z každé formy interakce s klientem. At’ už rozhovorem a pozorováním nebo za pomoci jakékoliv výzvové situace (setřídění karet, kamínků, dřívek, náhodná gesta, kresba čehokoliv a čímkoliv atp.). V nedávné době se v diagnostické praxi objevilo např. sestavování obrazců ze sirek. Je to postup projektivní, bez zatímní existence nějakých vyhodnotitelných parametrů. V rukou kvalifikovaného psychologa to však může být neobyčejně zajímavý nástroj s velkou výtěžností i proto, že je neobtěžující, prostý, má pro klienta silný vyzývací charakter. Na druhé straně je třeba před podobnými exkursy varovat především nezkušené a začínající psychology nebo dokonce laiky. Obtížně dokážou kontrolovat a vyhodnocovat téměř bezbřehé množství údajů, odlišovat je podle relevantnosti k základní otázce. Výsledkem může být pocit, tušení, že postup „něco ukazuje“.

Psychodiagnostika je vystavena nebezpečí prŕiliš snadného spolehnutí se na výsledek diagnostického testu a zvláště takového, který má ,image“, který má za sebou vědeckou společnost apod. Za podstatné považujeme logické a disciplinované myšlení každého jednoho psychodiagnostika. Apelování na správné myšlení a analyzování však nebývá vždy rádo slyšeno. Určitým důkazem je i již v textu výše zmíněná publikace slavného psychiatra Eugena Bleulera (1857-1939). V téměř zapomenuté publikaci (původně z roku 1922, další vydání 1962, 1985) Bleuler poukazuje na nesprávné myšlenkové postupy v medicíně, ale platnost toho je evidentně nadoborová. Disciplinované (anebo, řekněme dnešním běžným výrazem „kritické“) myšlení je takové, které umí vážit fakta, jejich kombinace a jejich přesnost, resp. nepřesnost. Disciplinované myšlení je potřeba (ba ještě více!) i tam, kde přesnosti a exaktnosti ubývá, kde ke slovu přicházejí pocity, prožitky, 
dojmy, krása. To je to, co spojuje vědce i umělce, co se sice obtížně definuje, ale co má vztah ke schopnosti zvažování, odstupu a v něm sledování toku obrazivosti, opětnému zhodnocování atp. Je to snad to, o čem psal již před sto lety Eugen Bleuler, když vyzýval $\mathrm{k}$ disciplinovanému myšlení v medicíně. Je nám, myslím, dostatečně jasné, že zdaleka nejde pouze o medicínu, ale obecně o způsob lidského myšlení.

Kromě jiného Bleuler poznamenává, že běžně dáváme klinické, anatomické a další nálezy do souvislosti s jinými skutečnostmi našeho života, aniž bychom měli důkazní materiál, který souvislost racionálně podloží. Je tedy třeba podporovat logiku spojení, s nimiž pracujeme. Nestačí, dodejme my, nacházená statistická souvislost. Ta nás nemůže zbavit zodpovědnosti za racionální výklad a náhled. Jinými slovy jde také o pečlivost našich myšlenkových experimentů, kterými odvozujeme pravidla, podle nichž se řídí svět kolem nás. ${ }^{2}$ Psychologická práce se ovšem o takovou myšlenkovou práci opírá velmi často (viz např. také jinde $\mathrm{v}$ tomto textu jeden z modelů diagnostického usuzování, zmíněný Weinerem (1998).

Klasik psychologické metodologie Holt (např. 1958, 1970) jako by anticipoval budoucí nástup kvalitativní metodologie, když tvrdí, že klinický a experimentální přístup spolu těsně souvisí a jako sjednocující moment vidí správnou formulaci problému a otázky. Jiný klasik, Meehl (1954) konstatuje, že klinikům bývá jako povinnost ukládáno statisticky prokázat, že jejich počínání je dostatečně korektní a přesné. Mnohdy je to na místě, píše Meehl, ale hned také rozlišuje situace, kdy jde o predikci nějakého jevu, chování a kdy se vychází skutečně jen ze statistických předpokladů (řrekněme napřr. při odhadu incidence nějaké poruchy v závislosti na rizikových faktorech), a situace, kdy je třeba do interpretace vnést psychologické porozumění kombinaci proměnných a jejich kvalit, jak je tomu při použití faktorové analýzy (např́íklad při predikci chování, očekávaného řešení nějaké životní situace na základě výsledného profilu v testu 16PF). V psychodiagnostice to znamená, že v závislosti se zvolenou otázkou a formulovaným problémem klademe různý důraz na exaktní, metrický, statistický postup v podobě vysoce objektivního testu a vedle toho na pochopení, klinické predikci i na zkušenosti. A nezřídka se to vše propojuje v jednom celkovém prediktivním procesu.

\section{Projektivní metody}

Věnujme se na tomto místě ještě některým zmíněným otázkám v souvislosti s projektivními technikami. Ty jsou stále mezi psychodiagnostiky mimořádně oblíbené, ale současně představují nejedno riziko a potřebu pečlivého uvažování. Výchozím fenoménem je percepce. Jak říkáme již jinde (Najbrtová, Šípek, Loneková, Čáp, 2017), můžeme chápat jev percepce jako promítnutí, extenzi, vržení před sebe. Podle Shneidmana (1965) je v projekci možné vidět téměř fyzickou extenzi psychologických atributů. Zde se téměř vnucuje zajímavá souvislost s tezemi Roberta Vischera (1847-1933), ${ }^{3}$ který řešil souvislost formy uměleckého díla (a de facto všeho jevového kolem nás) s našimi pocity. Vysvětloval to mimo vědomými procesy uplatňujícími se ve vnímání. Při vnímání forem je spojujeme s jakýmsi vitálním obsahem. Vischer použil dodnes používaný termín

Více o tématu viz také Šípek (2007).

3 Své názory uveřejnil Vischer v knize Über das optische Forgefühl: ein beitrag zur Aesthetik, vydané v roce 1873. 
vcitění, resp. empatie (německy Einfühlung). To, co je důležité, je to, že podle Vischera jde u empatie o nevědomé promítnutí, tedy projekci vlastní tělesné formy i psychiky (jako neodlučitelných fenoménů) do formy objektu. A ještě chvíli u náhledu umělecko-estetického zůstaňme (podrobněji viz Šípek 2010). Podle zmíněné Vischerovy představy lze estetický prožitek (řekněme libost) vysvětlit jako zvnějšněný sebeprožitek, kdy subjekt a objekt jsou propojeny. Vischer uvažuje o př́ijemném sebeprožitku, ale etický prožitek nemusí být nutně zabarven pouze libě (může navozovat napětí, neklid, obavy atp.). Vischer také poznamenává, že zrakový kontakt, vidění nemusí být vždy centrální pro výsledné prožívání. Podle tohoto autora jde o komplexní reakci prostorového chápání, imaginace, emocí. A tak vizuální podnět může být prožíván ani ne tak našima očima, ale jiným smyslem a v jiné části našeho těla. Vizuální vjem se tedy může projevit, rozeznít jako prožitek v celém těle. Vischer ovšem nebyl sám s podobnými názory. Mohli bychom zmínit, že např́íklad Adolf Hildebrand, který už v roce 1907 zdůrazňoval vnímání uměleckého (a jistěže i každodenního) jevu za pomoci pocitů těla, kdy se jakoby stáváme „větší či menšíi, abychom se danému objektu (např. také obrazu) přizpůsobili a s ním dobře ,ladili““.

Záměrně jsme se pustili mimo klasickou oblast klinickou, resp. psychopatologickou, kdy je bezpochyby možné jmenovat Freuda, který o projekci uvažoval jako o jednom z psychických obranných mechanismů. Všeobecně je známé, že projekcí je rozuměno přičítání vlastních psychických obsahů (žádostí, pohnutek) jiným osobám. Připomeňme si však (viz např́íklad Nakonečný 2009), že u Freuda se projekcí rozuměla nejen obrana proti úzkosti, ale obecně i princip ovlivňování vnímání podnětů vzpomínkami. Tím se uplatnění projekce rozšiřuje do každé percepce. Nakonečný také dále navazuje na další a na další autory v tom, že každé chování je ovlivněno projekcí stavu psychiky, resp. sestavou psychických reprezentací světa. Hned dodejme, že právě tento mechanismus je také sledován např. v Rorschachově testu. Připomeňme si také relevantní myšlenky C. G. Junga. ${ }^{4}$ Podle Junga je projekce obecným psychologickým mechanismem přenášejícím subjektivní obsahy nejrůznějšího druhu na objekt, který je vnímán a se kterým jsme v kontaktu. Je to aktivované nevědomí, které hledá svůj výraz. Nevědomé obsahy zprvu vždy vystupují jako projikované na objektivní osoby a vztahy, píše Jung (viz Jaffé 1998). Podle něho je vlastně všechno nevědomé tak či onak projikované. Blízko tomu je názor Knoblocha a Knoblochové (1999, str. 82): „V rámci skupinového schématu připisujeme naše vlastnosti, přání a tendence jiným lidem, skutečným i fiktivním. Tento jev nazýváme projekce;...".

Citujme však Junga (viz Jaffé 1998, str. 87) obšírněji: „Čím je pole vědomí u člověka omezenější, tím více se psychické obsahy [...] objevují jakoby mimo, bud' jako duchové, nebo magické potence, které jsou projikovány na živé bytosti (kouzelníky, čaroděje). Na určitém vyšším stupni vývoje [...] už nejsou všechna imaga projikována [...]; ten či onen komplex se přiblížil vědomí alespoň do té míry, že už není pocit’ován jako cizorodý..." Podle Jungova názoru fungovala psychika našich předchůdců ve větší propojenosti s okolím, na nějž se prožitky snadno vázaly, resp. se v něm zobrazovaly. Mnoho z toho, co pozorujeme kolem nás v prírodě a jak ji prožíváme, tedy její proměny, fáze, zvraty atp., je podle Junga vlastně symbolickým výrazem pro vnitřní nevědomá dramata duše. Lidské

Tyto Jungovy i některé další naše názory jsme prezentovali již dříve, viz Šípek (2000). Domníváme se však, že jejich prripomenutí zde bude jen ku prospěchu věci. 
vědomí to může uchopit a pochopit přes proces projekce, tedy zrcadlení v přírodních událostech. Jung není s termínem „projekce“ spokojen. To by předpokládalo nějaké vynětí, vytržení směrem ven, ale podle něho jde spíše o akty introjekce.

Dosud jsme o projekci uvažovali jako o výhradně nevědomém mechanismu. Až poté, co jsme schopni projektivní mechanismus alespoň částečně a $\mathrm{v}$ určitých podobách zvědomit, můžeme být i vědomými svědky možnosti nacházet souvislosti mezi naším psychickým děním a děním kolem nás. Také v projektivních technikách je to podobně složitější. Zde můžeme do jisté míry „projikovat“ také vědomě. Můžeme poměrně dobře a kontrolovaně imaginovat a nezřídka si uvědomovat zdroje našich nápadů a asociací. Pokud se zbavíme tíživých tlaků našeho nevědomí, našich nedořešených konfliktů, které mají tendenci se prodrat $\mathrm{v}$ nějaké pozměněné podobě ven, tak je projekce významným zdrojem tvořivosti. Je ovšem otázkou, jestli je zde ještě označení projekce adekvátní. Kromě projektivních technik by to zajisté platilo o celé oblasti umělecké tvorby, na jejímž začátku stojí mnohoznačnost a tvárnost podnětového materiálu.

Na tomto místě přebíráme naše pracovní chápání procesu projekce, jak jsme to (podrobněji) popsali již dř́ve (Najbrtová et. al. 2017). Naše psychika se vyznačuje snahou udržovat jakousi rovnováhu mezi systémem dosud vybudovaných mentálních reprezentací, resp. schémat světa i nás samých $\mathrm{v}$ něm ${ }^{5}$ a podněty vstupujícími zvenku. To se může projevit zhruba dvojím způsobem: $V$ prvém případě by šlo o obranu např. v podobě vyčleňování, přemíst'ování nežádoucích obsahů ven. To je ona klasická podoba projekce v podobě především mezilidské (tedy v podobě projekce na jiné osoby). Tím se udržuje rovnováha mezi tím co je ,jä“ a co je „ne-já“. V kritické situaci se tedy přemístí nežádoucí fenomén ven do oblasti „ne-já“. Svým způsobem zde obrana předchází v „útok“. Odštěpuje se bud’ část (tj. afektivní náboj od obsahu), anebo celý „závadný“ obsah (to by bylo $\mathrm{v}$ př́padě popření, úplného zatlačení do nevědomí apod.). Jiná verze této aktivní podoby projektivního mechanismu je představitelná jako více či méně systematické zasahování do očekávané podoby podnětů našeho okolí. Tak je to např. ve vnímání světa (tedy především lidí v něm) jako dobrého, zlého, slibného, lhostejného atp. Sem by patřilo více či méně záměrné a promyšlené scénování našeho okolí, zasahování do něj, napřr. zařizování bytu, volba způsobů odívání a vlastního vzhledu atp. Volně bychom mohli přejít do oblasti kreativity umělecké.

Jistou modifikací, byt' vnitřně samozřejmě velmi blízkou, by byla apercepce, tedy jakési naučené schéma percepce, které moduluje vnímané jevy ve smyslu jejich filtrování a „propouštěni“ jen těch, které mají již nějaké existující mentální reprezentace. Tedy takové reprezentace, které byly již vybudované, naučené. To je užitečný mechanismus do té míry, do jaké je takový systém dobře s realitou propojený, skutečně ji reprezentující a současně také pružný a připravený k žádoucím obměnám, korekturám. Jinými slovy jde o výběrovost pozornosti a vnímání. Má-li tento mechanismus podobu očekávání, ${ }^{6}$ potom ale můžeme také hovořit o jeho aktivnější podobě. Samostatně také můžeme uvažovat o promítání svého psychického stavu do oblastí vlastního chování, prožívání, myšlení. Jde např. o agresi, útěk, strach, výčitky, radost, projevy náklonnosti apod. To ovšem již projekcí nenazýváme, i když to našemu širokému chápání stále vyhovuje. Je dobře

\footnotetext{
5 O tom podrobně pojednává psychologie osobnosti i psychologie sociální.

6 A patrně cítíme, že označení ,,projekce“ zde jaksi nesedí, protože v něm implicitně očekáváme větší aktivitu, tedy řekněme aktivní pohyb. Z teorie i praxe Rorschachova testu jsme si však osvojili uvažovat i o pohybu pasivním. To by právě zde mohla být vhodná pomocná představa. Filtr pasivně reguluje kvalitu toho, co vstupuje dovnitř.
} 
představitelné, že naše osobnost je mozaikou řady „oblastí“, ,poli““, které/která jsou modifikována, scénována tak, aby to vyhovovalo „centrálním“ požadavkům našeho já. Sem by tedy patřil způsob neverbálního chování odpovídající psychickému naladění (výrazy tváře, gesta, držení těla apod.), ale i širší podoby sebestylizace/sebescénování. Ze všeho výše probíraného a diskutovaného plyne, jak je mechanismus projekce složitý a jak musíme být obezřetní, chceme-li ho využít v naší psychodiagnostické práci.

Projektivní metody a jejich používáni velmi dobře ukazují, že podstatným je zde psycholog-diagnostik a všechny používané metody jsou pomocné. Tento princip platí vždy, i když to někdy není tak zřejmé. Např. v situaci testování výkonovými metodami (při výběru řidičů atp.) se může zdát, že je možné testy prostě zadat a následně je standardním způsobem vyhodnotit a porovnat s normami. To vše je dnes mnohdy možné díky počítačovým verzím mnoha testů. Nicméně na počátku vždy musí stát odborník, psycholog, který celý projekt sestaví, prripraví, zdůvodní a nakonec ho bude interpretovat.

\section{Vždy záleží na tom, co chceme zjištovat}

V psychologických jevech zachycených projekcí se mísí dlouhodobější i aktuální stavy a není snadné je odlišit. To ovšem bývá pro diagnostiku důležité. Vždy je zcela podstatné, jak zní naše diagnostická otázka. Projektivní metody mají proměnlivou validitu a to na rozdíl od mnohých jiných, psychometricky podloženějších testových metod. Čím je zkušenější psycholog, tím může být i prŕinosnější, tedy i validnější zvolená projektivní metoda. Obecně to platí i o některých jiných, neprojektivních metodách, které se ovšem vyznačují značnou komplexností a výkladovou relativitou. V neposlední řadě se počítá také $\mathrm{s}$ jistou mírou vhledu do takového množství dat a s něčím, co můžeme pracovně nazvat „kvalifikovaná intuice“. Pomyslné nůžky kvantity a kvality se v soudobém používání ROR rozevřely ještě více. A přsesto, anebo právě proto, je ROR tak lákavou výzvou pro mnohé psychology, kterým nevadí, že svět má mnoho interpretačních rovin. Umějí se na nich pohybovat a sestavovat tím barvitější obraz. A také, do jaké míry se máme smírit s trendem v diagnostické práci poukazovat na problémy a nikoliv na silné stránky (pokud na ně nejsme přímo tázáni). Snad to svědčí o jakémsi nepsaném zakotvení psychodiagnostiky (a diagnostiky obecně), že vede k popsání problémů, slabých míst.

\section{Závěr}

V předchozím textu jsme chtěli připomenout několik neprŕiliš často zmiňovaných zásad v psychodiagnostice. Daly by se shrnout do několika upozornění, kroků či postupů. Domníváme se, že zásadní je co nejpřesnější formulování otázky či zakázky, která má být v psychodiagnostickém procesu zodpovězena. Její konečná podoba je pak na psychologovi v roli psychodiagnostika a nelze se vymlouvat na nepřesnou, prŕiliš širokou, či nezodpověditelnou otázku, kterou již dostal zadanou. Samožrejmě můžeme pokračovat upozorněním na potřebu používání co nejpřesnějších termínů a pojmenování nebo operacionalizace proměnných, které chceme zjišt'ovat. To nevylučuje psychologem namnoze jen tušených souvislostí, podob atp. Ale je třeba být si toho vědom. I na neurčitost je možné poukázat dostatečně zřetelně, tedy vědomě a dostatečně přesně. Proč nepoužít pro přiblížení nějaké 
paralely i z jiných oblastí? Pokud to pomůže pochopení podstaty problému, je to podle nás zcela namístě. Šíře, nevyčerpatelnost jevů psychiky je svým způsobem obdobná šíři a nevyčerpatelnosti podob vesmíru. Snad se to může zdát př́lišs poetické, ale koneckonců i poezie je jedním z divů psychické produkce.

\section{LITERATURA}

Bleuler, E. (1962). Das autistisch-undisziplinierte Denken in der Medizin und seine Überwindung. Berlin, Springer.

Čermák, I. \& Fikarová, T. (2012). Tematicko-apercepčni test: interpretačni perspektivy. Nové Zámky: Psychoprof.

Holt, R. R. (1958). Clinical and statistical prediction: a reformulation and some new data. J.Abn.Soc.Psychol. $56,1-12$.

Holt, R. R. (1970). Yet another look at clinicfal and statistical prediction. American Psychologist, 25, 4, 337-349.

Jaffé, A. (1998). Vzpominky, sny, myšlenky C. G. Junga. Praha: Atlantis.

Knobloch, F. \& Knoblochová, J. (1999). Integrovaná psychoterapie v akci. Praha: Grada.

Koch, K. (1972). Der Baumtest. Bern: Hans Huber Verlag.

Lečbych, M. (2016). Rorschachova metoda. Integrativni pristup k interpretaci. Praha: Grada.

Meehl, P. (1954). Clinical vs. statistical prediction: a theoretical analysis and review of the evidence. Minneapolis, Univ. Minnesota Press.

Najbrtová, K., Šípek, J., (Eds.), Loneková, K. \& Čáp, D. (2017). Projektivní metody v psychologické diagnostice. Praha: Portál.

Nakonečný, M. (2009). Psychologie osobnosti. Praha: Academia.

Stančák, A. (1996). Klinická psychodiagnostika dospelých. Nové Zámky: Psychoprof.

Svoboda, M. (Ed.), Humpolíček, P. \& Šnorek, V. (2013). Psychodiagnostika dospělých. Praha: Portál.

Šípek, J. (2007). Myšlení před sto lety. Psychologie dnes, 5, s. 54-55.

Šípek, J. (2010). Psychologické souvislosti scénické tvorby. Praha: KANT.

Široký, H. (1964). Uvedeni psychologa do psychiatrické léčebny. Brno: Masarykova univerzita.

Weiner I. B.(1998). Principles of Rorschach Interpretation. New Jersey, London: Lawrence Erlbaum.

PhDr. Markéta Niederlová, Ph.D., Univerzita Karlova, Filozofická fakulta, katedra psychologie, e-mail marketa.niederlova@ff.cuni.cz

Prof. PhDr. Jiři Šípek, CSc., Ph.D., Univerzita Karlova, Filozofická fakulta, katedra psychologie,e-mailjiri.sipek@ff.cuni.cz 